\title{
IMPACT OF DIFFERENT HABITAT PARAMETERS ON CARABID BEETLE ASSEMBLAGES IN SELECTED AREAS OF A FOREST-FIELD LANDSCAPE IN POLAND - 10 YEARS OF DATA
}

\author{
Axel Schwerk, Agata Jojczyk and Izabela Dymitryszyn \\ Warsaw University of Life Sciences - SGGW, Faculty of Civil and Environmental Engineering \\ Institute of Environmental Engineering, Department of Landscape Art \\ Nowoursynowska Street 166, 02-787 Warsaw, Poland \\ E-mails: aschwerk@yahoo.de, https://orcid.org/0000-0002-2284-3776 \\ agata.jojczyk@interia.pl,https://orcid.org/0000-0003-4993-3226 \\ dymitryszyn@wp.pl,https://orcid.org/0000-0001-8059-4838
}

Long-term data on carabid beetles assemblages on differently managed study sites in forests and open areas were analysed to study the impact of selected environmental factors on the carabid assemblages of both the individual study sites over the years and the set of all study sites in selected years.

Ordination separated forest stands from open areas along the first, and samples of 2011 from those of 2015 along the second axis. For study sites in forest stands in most cases, precipitation was a significant factor, especially precipitation in the year before the inventory. However, for the youngest forest site, the year of the study was most important, indicating a succession process. For study sites in open areas, both precipitation and temperature showed most often significant results. Analysing the impact of environmental factors on carabid assemblages in the full set of study sites in 2011 and 2015 revealed carbon content in the organic layer and distance from the nearest forest as significant factors.

The results of the study extend our knowledge on the impact of environmental factors on the formation of carabid beetle assemblages in rural landscapes, which is essential in the framework of developing biodiversity conservation strategies.

Keywords: Carabidae, carabid beetle, landscape, succession, forest, environmental engineering.

\section{INTRODUCTION}

An essential factor for the species diversity in a given landscape, i.e. the number of species over a large area or region (gamma-diversity) (WHITTAKER 1972, Anderson et al. 2011), is its habitat diversity (e.g. RrszKowski et al. 2002, Weibull et al. 2003, Purtauf et al. 2004, Hendrickx et al. 2007). However, this species diversity is influenced by environmental factors, both on the spatial level of the individual habitats as well as the overall landscape.

On the habitat level, one may ask about the meaning of environmental characteristics of the individual habitats for species diversity and if individual 
environmental factors have the same significance in different habitat types. Other environmental factors may influence on a larger spatial scale to a different extent the overall species diversity.

Some large-scale environmental factors (as precipitation or temperature) may affect the different habitats in a very similar way but differ from year to year. Even if many species show rather reproduced distribution patterns between years in a given landscape (JudAs et al. 2002, SCHWERK 2014), such factors might influence the overall species diversity. Other environmental factors, like for example soil parameters, maybe differently pronounced in the individual habitats and their impact on the species may differ from habitat to habitat. Moreover, individual habitats change due to the process of natural succession, during which also such factors change. Shape and speed of this process may strongly differ (e.g. Prach et al. 1993, YANG et al. 2005, SсHWERK \& SzYszKo 2011). As a result of ecological succession, the species composition in a given habitat may change over time in a directed manner. The species composition in the habitat can also be influenced by landscape-related factors, like the type of neighbouring habitats or distance to the next forest or lake (e.g. Burel 1989, Fournier \& Loreau 1999, Holland \& Fahrig 2000, Millán de la Peña et al. 2003, Tropek et al. 2013).

To understand the impact of different predictable and stochastic environmental factors on the formation of carabid beetle assemblages in rural landscapes is an essential issue because currently, we are observing a drastic decline in invertebrate fauna on a large scale, particularly demonstrated on the example of insects (e.g. Kotze \& O'Hara 2003, Brooks et al. 2012, HallMANN et al. 2017, Homburg et al. 2019). Carabid beetles efficiently reflect the environmental variation and bear indicator potential at various spatial scales (KoIvula 2011). Hence, they can be useful indicators in this regard.

However, to obtain robust data in order to deal with the aspects mentioned above, long-term studies are needed. One of such studies was initiated in a forest-field landscape in the west of Poland, during which various taxonomic groups were studied in open areas and forest sites of different management regime and age. In the present paper data of this long-term study on carabid beetles (Carabidae) on eight study sites carried out for ten years were analysed to study the impact of selected environmental factors on the carabid assemblages of individual study sites over the years and the set of all study sites in selected years. We wished to find out if the impact of the respective environmental parameters on carabid assemblages differs between forest stands and open areas and which of the parameters are of utmost importance for the formation of the carabid assemblages. 


\section{MATERIAL AND METHODS}

\section{Study sites and field methods}

The study was carried out on the research object "Krzywda" at Tuczno (western Poland, the Wałecki district) and surrounding forests (Fig. 1). This area is a heterogeneous landscape composed of different forests, agricultural and post-agricultural areas of different stages of succession, and watercourses and mires (DYMitrYSZYN et al. 2013). Eight study sites (five forest sites of different age and three open areas) were selected for carabid sampling (Table 1).

Carabid beetles were collected using pitfalls (BARBER 1931) during the period 20092018. At each study site, three pitfall traps in a distance of about $50 \mathrm{~m}$ or more from each other were installed. Traps located in different study sites were also separated by a distance of at about $50 \mathrm{~m}$ or more in order to represent independent samples (e.g. Digweed et al. 1995, Hoekman et al. 2017). The traps were jars with a funnel (upper diameter $10 \mathrm{~cm}$ ) installed above flush with the soil surface. A roof was installed a few $\mathrm{cm}$ above the funnel. The trapping fluid was $50 \mathrm{ml}$ ethylene glycol. The trapping period covered continuously mid-May to mid-September in each year. The traps were checked for proper functioning in about two-week intervals.

Determination and nomenclature of the individuals collected were carried out according to Freude et al. (2004).

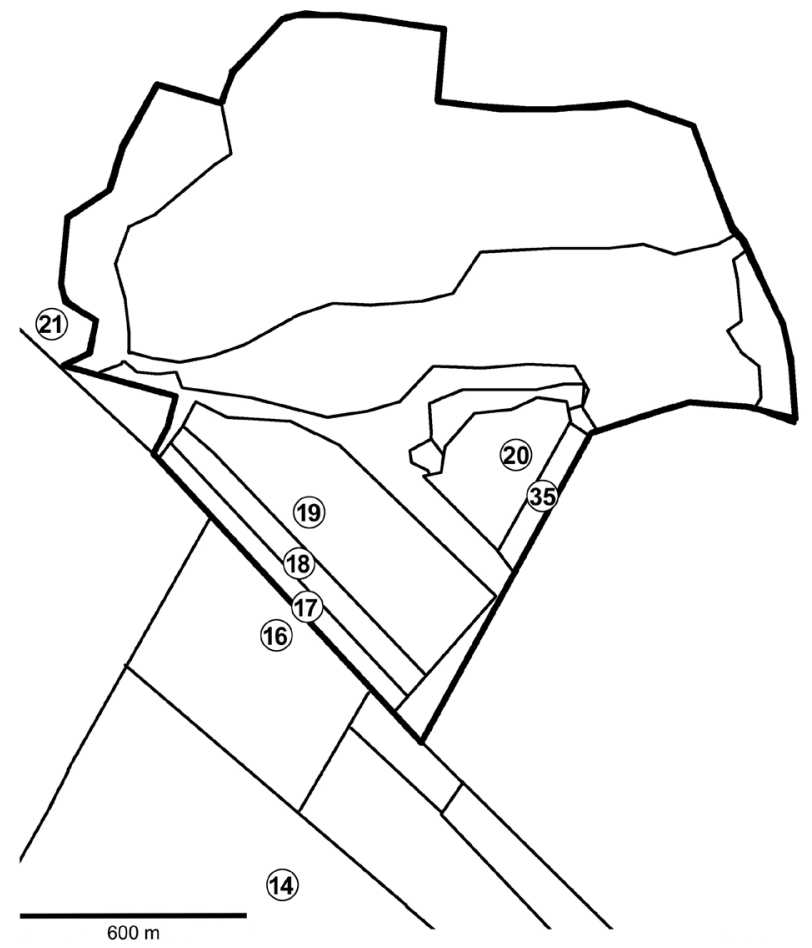

Fig. 1. Research object "Krzywda" with location of the study sites. Bold line - border of "Krzywda" 
Table 1. Types and description of the study sites (after Schwerk 2008, numbers of the study sites as in Fig. 1).

\begin{tabular}{lcl}
\hline Site type & Site number & Study site description \\
\hline Forest site & 14 & Planted pine forest, 12 years old in 2009 \\
Forest site & 16 & Planted pine forest, 31 years old in 2009 \\
Forest site & 20 & Naturally-regenerated pine forest, about 67 years old in 2009 \\
Forest site & 21 & $\begin{array}{l}\text { Naturally regenerated pine forest with a share of oak, beech } \\
\text { and birch, about 82 years old in 2009 }\end{array}$ \\
Forest site & 35 & Naturally-regenerated pine stand, about 10 years old in 2009 \\
Open area & 17 & Irregularly-mown site without biomass removal \\
Open area & 18 & Regularly-mown site with biomass removal \\
Open area & 19 & Irregularly-mown site without biomass removal \\
\hline
\end{tabular}

\section{Environmental parameters}

For each year of the study the following large-scale parameters were registered homogenously for all study sites: temperature $\left({ }^{\circ} \mathrm{C}\right)$ and precipitation in the year of inventory $(\mathrm{mm} /$ year $)$, temperature $\left({ }^{\circ} \mathrm{C}\right)$ and precipitation $(\mathrm{mm} /$ year $)$ in the preceding year, and the respective year itself (year of the study).

As parameters varied among the study sites, we registered the distance from the nearest forest $(\mathrm{m})$ and the age of the study site (age in the respective year) as well as the carbon content $(\mathrm{C} \%)$ in the organic layer and the carbon content $(\mathrm{C} \%)$ in the mineral soil, which were elaborated for the years 2011 and 2015.

For the forest stands the stand age in the respective year was taken as age, whereas the open study sites were characterised with an age of 0 years (regularly-mown site with biomass removal) and 1 year respectively (irregularly-mown sites without biomass removal), based on cutting intensity and biomass treatment. Data for temperature (mean temperature for the respective year) and precipitation (total precipitation in the respective year) were taken for the closest location (Piła) from the Institute of Meteorology and Water Management - National Research Institute resources.

Values of carbon content were elaborated as follows: Soil samples were collected in the close neighbourhood of each pitfall trap in August 2011 and between October and November in 2015. On both forest sites and open areas, soil samples from mineral layers were taken from the depth of $0-5 \mathrm{~cm}$. In the case of forest sites, additional material from organic layers was taken as samples. The collected soil samples were prepared for laboratory analysis according to the Polish standard no. PN-ISO 10694:2002. Organic carbon content was determined by applying the elemental analysis method according to the Polish standard no. PN-ISO 10694:2002 on a Wario Max CN apparatus.

\section{Statistical methods}

For each study site and year, the carabid beetle catches of the three traps were pooled. For each of these samples, the numbers of species and individuals were calculated, resulting in one value for these two parameters for each study site per year. Accordingly, for the years 2011 and 2015 carbon values for carbon contents in the organic layer and mineral soil were 
determined, calculating for each study site the respective mean values of the samples. For the open areas with a missing organic layer, zero values were used in statistical analyses.

In order to analyse the significance of the impact of the environmental factors on the carabid assemblages, constraint gradient analyses were conducted using Canoco for Windows 4.56 and CanoDraw for Windows 4.14 (ter BrAAK 1987, TER BRAAK \& ŠMILAuer 2002). DCCA was first used to select the appropriate statistical model based on the longest gradient (Lepš \& Šmilauer 2003) and then Redundancy Analyses (RDA) and Canonical Correspondence Analysis (CCA) were carried out.

In gradient analysis with the individual study sites over the years (2009-2018) as samples, year (year of the study), temperature $\left({ }^{\circ} \mathrm{C}\right)$ and precipitation (mm/year) in the year of inventory, and temperature $\left({ }^{\circ} \mathrm{C}\right)$ and precipitation $(\mathrm{mm} /$ year $)$ in the preceding year were included as environmental parameters.

For the years 2011 and 2015, all study sites were included as samples. In these analyses age (age in the respective year), carbon content $(\mathrm{C} \%)$ in the organic layer, carbon content $(\mathrm{C} \%)$ in the mineral soil and distance from the nearest forest $(\mathrm{m})$ were included as environmental parameters.

The samples of all study sites for 2011 and 2015 were together analysed with year (year of the study), temperature $\left({ }^{\circ} \mathrm{C}\right)$ and precipitation $(\mathrm{mm} /$ year) in the year of inventory, temperature $\left({ }^{\circ} \mathrm{C}\right.$ ) and precipitation (mm/year) in the preceding year, age (age in the respective year), carbon content $(\mathrm{C} \%)$ in the organic layer, carbon content $(\mathrm{C} \%)$ in the mineral soil and distance from the nearest forest $(\mathrm{m})$ included as environmental parameters.

In all gradient analyses, dominance values (percentage share of the respective species in a sample) for the carabid species at the different sites were used. Redundancy Analyses (RDA) were conducted with scaling focused on inter-sample distances and no post-transformation of species scores. In the case of Canonical Correspondence Analyses (CCA) we used scaling focused on inter-sample distances and Hill's scaling. As dominance values were used, the data were not transformed in any gradient analysis. The significance of the individual environmental variables included in the respective RDA or CCA was tested applying Monte Carlo permutation tests (unrestricted, 499 permutations) with the automatic forward selection of variables (reduced model) as well as manual selection for each variable separately.

\section{RESULTS}

\section{Basic results}

Altogether, 9208 individuals belonging to 77 species were collected. The most common species, represented by more than 400 individuals, were Pterostichus niger (2600 individuals), Calathus fuscipes (1043 individuals), Pterostichus oblongopunctatus (599 individuals), Poecilus versicolor (489 individuals), Carabus hortensis (437 individuals), Amara lunicollis (430 individuals), and Harpalus rubripes (409 individuals). The total numbers of individuals showed strong fluctuations between the years, whereas the total numbers of species stayed relatively constant (Appendix 1).

Some differences concerning distance from the nearest forest and carbon contents were revealed depending on the habitat type. The open areas were between 50 and $150 \mathrm{~m}$ away from forests. Differences in carbon contents were 
particularly due to the lack of an organic layer on the open areas. Regarding the data on temperature and precipitation, an increase in mean yearly temperature and a decrease in total precipitation over the years of the study could be observed (Appendices $2 \& 3$ ).

\section{Individual study sites over the period 2009-2018}

Concerning the forest sites (Table 2) precipitation in the preceding year (study sites 14 and 20), precipitation (study site 21) and the year of the study (study site 35) were detected as significant environmental factors when using forward selection. For the study site 16, no factor showed a significant result, but precipitation in the preceding years was closest to being significant. When using manual selection temperature was also a significant factor for study site 35 .

Regarding the open areas (Table 3 ) both temperature (study site 17) and precipitation (study site 18) showed significant results when using forward selection. Concerning the study site 19, no factor was significant, but the temperature was closest. Using manual selection, as additional significant factors, precipitation and the year of study were detected for the study site 17 and temperature in the preceding year for the study site 18.

Set of all study sites in the years 2011, 2015 and 2011+2015

Analysing all study sites together for the year 2011 (Table 4) carbon content in the organic layer was significant when using forward selection. Using manual selection, the distance from the nearest forest was detected as an additional significant factor. The same results were obtained when analysing all study sites together for the year 2015 (Table 4).

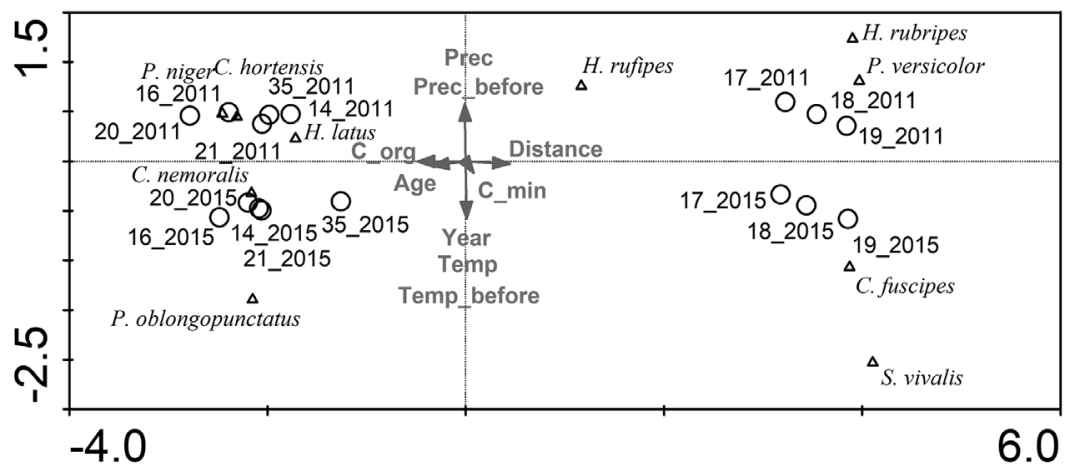

Fig. 2. Ordination plot based on Canonical Correspondence Analysis (CCA) of the results for sites (open circles), species with largest impact on the analysis results (open triangles) and environmental variables (arrows) for the total set of all study sites, years 2011+2015 
Table 2. Redundancy Analysis (RDA) of the forest study sites (14, 16, 20, 21, 35): Results of Monte Carlo permutation tests of the environmental variables tested separately and using automatic forward selection of variables (reduced model). Lambda-1 - variance explained by the environmental variables separately, Lambda-A - additional variance explained when included in the model using forward selection.

\begin{tabular}{|c|c|c|c|c|c|c|}
\hline \multirow{2}{*}{ Variable } & \multicolumn{3}{|c|}{ Tested separately } & \multicolumn{3}{|c|}{ Forward selection } \\
\hline & Lambda-1 & $\mathrm{F}$ & $P$ & Lambda-A & $\mathrm{F}$ & $P$ \\
\hline \multicolumn{7}{|c|}{ Study site 14} \\
\hline Prec $_{\text {before }}$ & 0.49 & 7.65 & 0.004 & 0.49 & 7.65 & 0.004 \\
\hline Year & 0.24 & 2.52 & 0.092 & 0.10 & 1.79 & 0.152 \\
\hline Temp $p_{\text {before }}$ & 0.21 & 2.07 & 0.122 & 0.04 & 0.65 & 0.678 \\
\hline Temp & 0.04 & 0.36 & 0.832 & 0.09 & 1.65 & 0.174 \\
\hline Prec & 0.03 & 0.22 & 0.934 & 0.05 & 0.98 & 0.478 \\
\hline \multicolumn{7}{|c|}{ Study site 16} \\
\hline Prec $_{\text {before }}$ & 0.22 & 2.26 & 0.110 & 0.22 & 2.26 & 0.110 \\
\hline Year & 0.11 & 0.94 & 0.344 & 0.10 & 1.09 & 0.368 \\
\hline Temp $p_{\text {before }}$ & 0.09 & 0.81 & 0.448 & 0.10 & 1.02 & 0.334 \\
\hline Temp & 0.04 & 0.36 & 0.818 & 0.04 & 0.35 & 0.728 \\
\hline Prec & 0.03 & 0.28 & 0.944 & 0.11 & 1.10 & 0.324 \\
\hline \multicolumn{7}{|c|}{ Study site 20} \\
\hline Prec $_{\text {before }}$ & 0.37 & 4.66 & 0.032 & 0.37 & 4.66 & 0.032 \\
\hline Year & 0.31 & 3.61 & 0.062 & 0.17 & 2.54 & 0.170 \\
\hline Temp $p_{\text {before }}$ & 0.19 & 1.84 & 0.202 & 0.07 & 0.97 & 0.370 \\
\hline Prec & 0.17 & 1.70 & 0.216 & 0.05 & 0.85 & 0.422 \\
\hline Temp & 0.15 & 1.43 & 0.258 & 0.01 & 0.16 & 0.908 \\
\hline \multicolumn{7}{|l|}{ Study site 21} \\
\hline Prec & 0.42 & 5.80 & 0.010 & 0.42 & 5.80 & 0.010 \\
\hline Temp $p_{\text {before }}$ & 0.26 & 2.86 & 0.108 & 0.01 & 0.18 & 0.886 \\
\hline Prec $_{\text {before }}$ & 0.21 & 2.16 & 0.168 & 0.15 & 2.51 & 0.128 \\
\hline Temp & 0.13 & 1.19 & 0.322 & 0.01 & 0.09 & 0.960 \\
\hline Year & 0.07 & 0.60 & 0.556 & 0.05 & 0.75 & 0.460 \\
\hline \multicolumn{7}{|c|}{ Study site 35} \\
\hline Year & 0.58 & 10.99 & 0.010 & 0.58 & 10.99 & 0.010 \\
\hline Temp & 0.51 & 8.317 & 0.010 & 0.11 & 2.86 & 0.066 \\
\hline Prec & 0.34 & 4.11 & 0.060 & 0.01 & 0.16 & 0.948 \\
\hline Temp $p_{\text {before }}$ & 0.29 & 3.33 & 0.082 & 0.02 & 0.66 & 0.570 \\
\hline Prec $_{\text {before }}$ & 0.23 & 2.38 & 0.126 & 0.08 & 1.57 & 0.180 \\
\hline
\end{tabular}


Table 3. Redundancy Analysis (RDA) of the open study sites (17, 18, 19): Results of Monte Carlo permutation tests of the environmental variables tested separately and using automatic forward selection of variables (reduced model). Lambda-1 - variance explained by the environmental variables separately, Lambda-A - additional variance explained when included in the model using forward selection.

\begin{tabular}{|c|c|c|c|c|c|c|}
\hline \multirow{2}{*}{ Variable } & \multicolumn{3}{|c|}{ Tested separately } & \multicolumn{3}{|c|}{ Forward selection } \\
\hline & Lambda-1 & $\mathrm{F}$ & $P$ & Lambda-A & $\mathrm{F}$ & $p$ \\
\hline \multicolumn{7}{|l|}{ Study site 17} \\
\hline Temp & 0.35 & 4.35 & 0.016 & 0.35 & 4.35 & 0.016 \\
\hline Prec & 0.31 & 3.58 & 0.018 & 0.11 & 1.46 & 0.210 \\
\hline Year & 0.28 & 3.13 & 0.038 & 0.08 & 1.02 & 0.386 \\
\hline Prec $_{\text {before }}$ & 0.05 & 0.46 & 0.760 & 0.06 & 0.73 & 0.554 \\
\hline Temp $p_{\text {before }}$ & 0.04 & 0.37 & 0.836 & 0.10 & 1.32 & 0.274 \\
\hline \multicolumn{7}{|l|}{ Study site 18} \\
\hline Prec & 0.33 & 4.00 & 0.004 & 0.33 & 4.00 & 0.004 \\
\hline Temp $p_{\text {before }}$ & 0.24 & 2.53 & 0.046 & 0.08 & 1.05 & 0.390 \\
\hline Year & 0.22 & 2.31 & 0.060 & 0.05 & 0.76 & 0.576 \\
\hline Temp & 0.21 & 2.14 & 0.094 & 0.11 & 1.53 & 0.184 \\
\hline Prec $_{\text {before }}$ & 0.16 & 1.49 & 0.166 & 0.13 & 1.68 & 0.134 \\
\hline \multicolumn{7}{|l|}{ Study site 19} \\
\hline Temp & 0.20 & 1.97 & 0.088 & 0.20 & 1.97 & 0.088 \\
\hline Prec & 0.15 & 1.44 & 0.244 & 0.06 & 0.56 & 0.762 \\
\hline Year & 0.15 & 1.37 & 0.252 & 0.06 & 0.61 & 0.746 \\
\hline Prec $_{\text {before }}$ & 0.12 & 1.10 & 0.412 & 0.12 & 1.23 & 0.282 \\
\hline Temp $p_{\text {before }}$ & 0.04 & 0.32 & 0.906 & 0.12 & 1.33 & 0.254 \\
\hline
\end{tabular}

The whole set of study sites for 2011 and 2015 together (Table 4) revealed carbon content in the organic layer and precipitation as significant factors when using forward selection. Additional significant factors were the distance from the nearest forest and the age of the study site when using manual selection. The first canonical axis of the CCA explained $38.6 \%$ of the variation in species data and $62.0 \%$ of that in the species-environment relationship. The second canonical axis explained $13.1 \%$ and $21.2 \%$, respectively. As shown in the ordination diagram (Fig. 2), the forest sites were separated from open sites along the first ordination axis, with carbon content in the organic layer and age of the study sites positively correlated with the forest sites and distance from the nearest forest positively correlated with the open sites. Characteristic forest species as Carabus hortensis and Pterostichus niger were located close to 
Table 4. Canonical Correspondence Analysis (CCA) of the total set of all study sites in the years 2011, 2015, and 2011+2015: Results of Monte Carlo permutation tests of the environmental variables tested separately and using automatic forward selection of variables (reduced model). During forward selection of variables for all study sites - 2011+2015

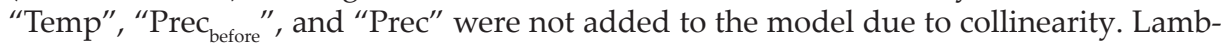
da-1 - variance explained by the environmental variables separately, Lambda-A - addi-

tional variance explained when included in the model using forward selection.

\begin{tabular}{|c|c|c|c|c|c|c|}
\hline \multirow{2}{*}{ Variable } & \multicolumn{3}{|c|}{ Tested separately } & \multicolumn{3}{|c|}{ Forward selection } \\
\hline & Lambda-1 & $\mathrm{F}$ & $P$ & Lambda-A & $\mathrm{F}$ & $p$ \\
\hline \multicolumn{7}{|c|}{ All study sites - 2011} \\
\hline $\mathrm{C}_{\text {org }}$ & 0.92 & 5.65 & 0.007 & 0.92 & 5.65 & 0.007 \\
\hline Distance & 0.76 & 4.04 & 0.011 & 0.14 & 0.84 & 0.458 \\
\hline Age & 0.48 & 2.074 & 0.069 & 0.13 & 0.68 & 0.721 \\
\hline $\mathrm{C}_{\min }$ & 0.15 & 0.522 & 0.827 & 0.15 & 0.86 & 0.524 \\
\hline \multicolumn{7}{|c|}{ All study sites - 2015} \\
\hline $\mathrm{C}_{\text {org }}$ & 0.86 & 4.81 & 0.012 & 0.86 & 4.81 & 0.012 \\
\hline Distance & 0.77 & 3.99 & 0.002 & 0.17 & 0.94 & 0.496 \\
\hline Age & 0.51 & 2.149 & 0.072 & 0.10 & 0.53 & 0.854 \\
\hline $\mathrm{C}_{\min }$ & 0.10 & 0.31 & 0.986 & 0.10 & 0.42 & 0.816 \\
\hline \multicolumn{7}{|c|}{ All study sites - 2011+2015 } \\
\hline $\mathrm{C}_{\text {org }}$ & 0.88 & 7.67 & 0.002 & 0.88 & 7.67 & 0.002 \\
\hline Distance & 0.74 & 5.99 & 0.002 & 0.08 & 0.70 & 0.764 \\
\hline Age & 0.48 & 3.33 & 0.006 & 0.07 & 0.63 & 0.860 \\
\hline Prec & 0.18 & 1.08 & 0.298 & 0.17 & 1.62 & 0.048 \\
\hline Temp & 0.18 & 1.08 & 0.236 & - & - & - \\
\hline Prec $_{\text {before }}$ & 0.18 & 1.08 & 0.300 & - & - & - \\
\hline Temp $p_{\text {before }}$ & 0.18 & 1.08 & 0.310 & - & - & - \\
\hline Year & 0.18 & 1.08 & 0.278 & - & - & - \\
\hline $\mathrm{C}_{\min }$ & 0.09 & 0.541 & 0.900 & 0.07 & 0.57 & 0.902 \\
\hline
\end{tabular}

the forest sites, and species typical for open areas (e.g. Calathus fuscipes, Poecilus versicolor) were located close to the open sites. The assemblages of the year 2011 were separated from those of the year 2015 along the second ordination axis. Precipitation in the years of study and precipitation in the preceding year were positively correlated with assemblages from 2011. The temperature in the years of study, temperature in the preceding year and year of the study were positively correlated with the assemblages from 2015. 


\section{DISCUSSION}

The results indicated that on individual forest study sites precipitation (particularly precipitation in the year before the inventory) was an important factor, whereas in open areas both precipitation and temperature showed some significant results. The more substantial influence of precipitation in forest habitats may be explained by shading due to the tree crowns. In unshaded, open habitats, however, the temperature may become a dominant factor because of the stronger impact of direct sunlight. Except for desert steppe, TsaFACK et al. (2019) detected climatic factors, in particular temperature, as the most critical factors for variability in carabid species composition in grassland ecosystems in China. TuF et al. (2012) demonstrated temperature-dependent differences in activity patterns of individual carabid beetle species between a forest and a clear cut area. In accordance with our results described above, regarding the youngest forest site (study site 35) temperature was a significant factor. However, the most important factor for this study site was the year of the study, indicating a succession process. This result corroborates earlier observations made for this study site (SCHWERK \& SzYSZKo 2012). Samples collected till 2013 were clearly separated from those elaborated after 2013, what may be connected to canopy closure. In a study on boreal carabid beetle assemblages, Koivula et al. (2002) revealed the canopy closure distinguished the open phases from the closed ones, the catches showing a drastic decrease and assemblage level change.

When comparing all study sites together, forest habitats were clearly separated from open habitats, indicated by carbon content in the organic layer and distance from the nearest forest as significant factors. This result supports the importance of habitat diversity for the formation of diversified carabid beetle assemblages and species richness in the landscape. The relevance of precipitation was supported by being a significant factor in separating the study sites in 2011 from 2015. Regarding the forest habitats, it turned out the organic layer was of very high importance since the factor carbon contents in the organic layer overruled the factor age of the study sites. For many carabid species, this layer has essential functions, for example as a refugee after habitat disturbances, as a place for foraging or for laying the eggs (e.g. van Heerdt et al. 1976, BAuer 1981, Skıodowski 2017). Koivula et al. (1999) showed a significant influence of leaf litter on carabid abundance in forests in central Finland. Carbon contents in the mineral soil did not have a significant impact. However, this result may be influenced by the history of the study sites, because all of them except study site 21 (naturally regenerated pine forest with a share of oak, beech and birch) were used as agricultural fields in the past (DYMitryszrn et al. 2013). Soil preparation practices as ploughing may have influenced the formation of the carabid assemblages (e.g. SкŁodowsKI 
2005, Kosewska et al. 2018). It should be noted that compared to other brown soils of the Palearctic region, the soils in our study area are sandy soils with a limited amount of soil organic carbon. Thus, the importance of soil organic content in our study is evident.

Although habitat diversity can be assessed as a key factor for species diversity in landscape, different predictable and stochastic environmental factors (climatic factors) may affect the carabid beetle composition on individual sites. For example, Judas et al. (2002) demonstrated that mesoscale (pitfall density of $10-50 \mathrm{~km}^{-2}$ ) variation in soil and microclimate govern spatial population structure of several carabid beetle species in topographically varied beechwood landscape. Besides, ecological succession on individual study sites is a process, which has some influence on both the environmental factors in the respective habitat and degree of habitat diversity in the landscape (SFerra et al. 2017, Hilmers et al. 2018). However, another important aspect is climate change. Climatic changes may have a direct impact on insect species regarding the range of expansion, growth, phenology or population genetics, and an indirect one due to effect on plants species (JAWORSKI \& HilszCZAŃsKI 2013, Pureswaran et al. 2018).

The results of the study extend our knowledge on the impact of different predictable and stochastic environmental factors on the formation of carabid beetle assemblages in rural landscapes. Nowadays, to counteract the decline in insect diversity is a serious task. Concerning this matter, the results of our study can play an essential role in the framework of developing biodiversity conservation strategies. We assume that active management of habitats (ecological or environmental engineering) can be a helpful tool when it comes to the implementation of such strategies.

Acknowledgements - The authors thank K. Hannig for confirming the identification of beetles difficult to identify, G. Gajewski for improving the English and an anonymous reviewer for valuable comments on earlier drafts of the manuscript. This paper is communication no. 532 in the tradition of the Laboratory of Evaluation and Assessment of Natural Resources, Warsaw University of Life Sciences - SGGW.

\section{REFERENCES}

Anderson, M. J., Crist, T. O., Chase, J. M., Vellend, M., Inouye, B. D., Freestone, A. L., Sanders, N. J., Cornell, H. V., Comita, L. S., Davies, K. F., Harrison, S. P., Kraft, N. J. B., Stegen, J. C. \& Swenson, N. G. (2011): Navigating the multiple meanings of B diversity: a roadmap for the practicing ecologist. - Ecology Letters 14: 19-28. https:// doi.org/10.1111/j.1461-0248.2010.01552.x 
BARber, H. S. (1931): Traps for cave inhabiting insects. - Journal of the Elisha Mitchell Scientific Society 46: 259-266.

BAUER, T. (1981): Prey capture and structure of the visual space of an insect that hunts by sight on the litter layer (Notiophilus biguttatus F., Carabidae, Coleoptera). - Behavioral Ecology and Sociobiology 8: 91-97. https://doi.org/10.1007/BF00300820

Brooks, D. R., Bater, J. E., Clark, S. J., Monteith, D. T., Andrews, C., Corbett, S. J., Beaumont, D. A. \& Chapman, J. W. (2012): Large carabid beetle declines in a United Kingdom monitoring network increases evidence for a widespread loss in insect biodiversity. - Journal of Applied Ecology 49: 1009-1019. https://doi.org/10.1111/j.13652664.2012.02194.x

Burel, F. (1989): Landscape structure effects on carabid beetles spatial patterns in western France. - Landscape Ecology 2: 215-226. https://doi.org/10.1007/BF00125092

Digheed, S. C., Currie, C. R., Carcamo, H. A. \& Spence, J. R. (1995): Digging out the “digging-in effect" of pitfall traps: Influences of depletion and disturbance on catches of ground beetles (Coleoptera: Carabidae). - Pedobiologia 39: 561-576.

Dymitryszyn I., Szyszko J. \& Rylke, J. (eds) (2013): Terenowe metody oceny i wyceny zasobów przyrodniczych / Field methods of evaluation and assessment of natural resources. - WULSSGGW Press, Warsaw, 264 pp.

Fournier, E. \& Loreau, M. (1999): Effects of newly planted hedges on ground-beetle diversity (Coleoptera, Carabidae) in an agricultural landscape. - Ecography 22: 87-97. https://doi.org/10.1111/j.1600-0587.1999.tb00457.x

Freude, H., Harde, K.-W., Lohse, G. A. \& Klausnitzer, B. (2004): Die Käfer Mitteleuropas. Bd. 2, Adephaga 1, Carabidae (Laufkäfer). 2. (erweiterte) Aufl. - Spektrum, Heidelberg/ Berlin, $521 \mathrm{pp}$.

Hallmann, C. A., Sorg, M., Jongejans, E., Siepel, H., Hofland, N., Schwan, H., Stenmans, W., Muller, A., Sumser, H., Horren, T., Goulson, D. \& de Kroon, H. (2017): More than 75 percent decline over 27 years in total flying insect biomass in protected areas. - PLoS ONE 12: 1-21. https://doi.org/10.1371/journal.pone.0185809

Hendrickx, F., Maelfait, J.-P., van Wingerden, W., Schweiger, O., Speelmans, M., Aviron, I., Augenstein, I., Billeter, R., Bailey, D., Bukacek, R., Burel, F., Diekötter, T., Dirksen, J., Herzog, F., Lira, J., Roubalova, M., Vandomme, V. \& Bugter, R. (2007): How landscape structure, land-use intensity and habitat diversity affect components of total arthropod diversity in agricultural landscapes. - Journal of Applied Ecology 44: 340-351. https://doi.org/10.1111/j.1365-2664.2006.01270.x

Hilmers, T., Friess, N., Bässler, C., Heurich, M., Brandl, R., Pretzsch, H., Seidd, R. \& MüLleR, J. (2018): Biodiversity along temperate forest succession. - Journal of Applied Ecology 55: 2756-2766. https://doi.org/10.1111/1365-2664.13238

Hoekman, D., LeVan, K. E., Ball, G. E., Browne, R. A., Davidson, R. L., Erwin, T. L., Knisley, C. B., LaBonte, J. R., Lundgren, J., Maddison, D. R., Moore, W., Niemelä, J., Ober, K. A., Pearson, D. L., Spence, J. R., Will, K. \& Work, T. (2017): Design for ground beetle abundance and diversity sampling within the National Ecological Observatory Network. - Ecosphere 8: e01744. 10.1002/ecs2.1744. https://doi.org/10.1002/ ecs2.1744

Holland, J. \& FAHrig, L. (2000): Effect of woody borders on insect density and diversity in crop fields: a landscape-scale analysis. - Agriculture, Ecosystems and Environment 78: 115-122. https://doi.org/10.1016/S0167-8809(99)00123-1

Homburg, K., Drees, C., Boutaud, E., Nolte, D., Schuett, W., Zumstein, P., von RuschkowsKI, E. \& Assmann, T. (2019): Where have all the beetles gone? Long-term study reveals 
carabid species decline in a nature reserve in Northern Germany. - Insect Conservation and Diversity 12: 268-277. https://doi.org/10.1111/icad.12348

JAwORSKI, T. \& HiLszCZAŃski, J. (2013): The effect of temperature and humidity changes on insects development and their impact on forest ecosystems in the context of expected climate change. - Leśne Prace Badawcze (Forest Research Papers) 74: 345-355. https://doi. org/10.2478/frp-2013-0033

Judas, M., Dornieden, K. \& Strothmann, U. (2002): Distribution patterns of carabid beetle species at the landscape-level. - Journal of Biogeography 29: 491-508. https://doi. org/10.1046/j.1365-2699.2002.00697.x

Koivula, M. J. (2011): Useful model organisms, indicators, or both? Ground beetles (Coleoptera, Carabidae) reflecting environmental conditions. - ZooKeys 100: 287-317. https://doi.org/10.3897/zookeys.100.1533

Koivula, M., KukKonen, J. \& Niemelä, J. (2002): Boreal carabid-beetle (Coleoptera, Carabidae) assemblages along the clear-cut originated succession gradient. - Biodiversity and Conservation 11: 1269-1288. https://doi.org/10.1023/A:1016018702894

Koivula, M., Punttila, P., Haila, Y. \& Niemelä, J. (1999): Leaf litter and the small-scale distribution of carabid beetles (Coleoptera, Carabidae) in the boreal forest. - Ecography 22: 424-435. https://doi.org/10.1111/j.1600-0587.1999.tb00579.x

Kosewska, A., Topa, E., Nietupski, M. \& KĘDzior, R. (2018): Assemblages of carabid beetles (Col. Carabidae) and ground-dwelling spiders (Araneae) in natural and artificial regeneration of pine forests. - Community Ecology 19: 156-167. https://doi. org/10.1556/168.2018.19.2.8

Kotze, D. J. \& O'Hara, R. B. (2003): Species decline - but why? Explanations of carabid beetle (Coleoptera, Carabidae) declines in Europe. - Oecologia 135: 138-148. https:// doi.org/10.1007/s00442-002-1174-3

LePš, J. \& Šmilauer, P. (2003): Multivariate analysis of ecological data using CANOCO. - Cambridge University Press, Cambridge, 284 pp. https://doi.org/10.1017/ CBO9780511615146

Prach, K., PYšEK, P. \& Šmilauer, P. (1993): On the rate of succession. - Oikos 66: 343-346. https://doi.org/10.2307/3544823

Millán de la Peña, N., Butet, A., Delettre, Y., Morant, P. \& Burel, F. (2003): Landscape context and carabid beetles (Coleoptera: Carabidae) communities of hedgerows in western France. - Agriculture, Ecosystems and Environment 94: 59-72. https://doi. org/10.1016/S0167-8809(02)00012-9

Pureswaran, D. S., Roques, A. \& Battisti, A. (2018): Forest insects and climate change. Current Forestry Reports 4: 35-50. https://doi.org/10.1007/s40725-018-0075-6

Purtauf, T., Dauber, J. \& Wolters, V. (2004): Carabid communities in the spatio-temporal mosaic of a rural landscape. - Landscape and Urban Planning 67: 185-193. https://doi. org/10.1016/S0169-2046(03)00038-0

Ryszkowski, L., Karg, J., Kujawa, K., Goldyn, H. \& Arczynska-Chudy, E. (2002): Influence of landscape mosaic structure on diversity of wild plant and animal communities in agricultural landscapes of Poland. Pp. 185-217. In: Rүszкоwsкi, L. (ed.): Landscape ecology in agrosystems management. - CRC Press LLC, Boca Raton, Florida, USA. https://doi.org/10.1201/9781420041378-8

Schwerk, A. (2008): Model of the rate of succession of epigeic carabid beetles (Coleoptera: Carabidae) on degraded areas. - Instytut Badwczy Leśnictwa, Sękocin Stary, 71 pp.

Schwerk, A. (2014): Distribution and spatial autocorrelation of carabid species in differently treated post-agricultural areas. - Baltic Journal of Coleopterology 14: 141-150. 
Schwerk, A. \& Szyszko, J. (2011): Model of succession on degraded areas based on carabid beetles (Coleoptera: Carabidae). - ZooKeys 100: 319-332. https://doi.org/10.3897/ zookeys.100.1534

Schwerk, A. \& Szyszko, J. (2012): Variation in epigeic carabid fauna (Coleoptera: Carabidae) on differently-treated post-agricultural land. - Baltic Journal of Coleopterology 12: 39-48.

Sferra, C. O., Hart, J. L. \& Howeth, J. G. (2017): Habitat age influences metacommunity assembly and species richness in successional pond ecosystems. - Ecosphere 8: e01871. https://doi.org/10.1002/ecs2.1871

SкŁodowsкI, J. (2005): Zooindykacyjna ocena różnych sposobów przygotowania gleby przy zalesieniach gruntów porolnych. - Sylwan 149: 3- 12. [in Polish]

SKŁodowsKI, J. (2017): Manual soil preparation and piles of branches can support ground beetles (Coleoptera, Carabidae) better than four different mechanical soil treatments in a clear-cut area of a closed-canopy pine forest in northern Poland. - Scandinavian Journal of Forest Research 32: 123-133. https://doi.org/10.1080/02827581.2016.1195868

TER BRAAK, C. J. F. (1987): CANOCO - A FORTRAN program for canonical community ordination by [partial][detrended][canonical] correspondence analysis, principal components analysis and redundancy analysis (version 2.1). - DLO Agricultural Mathematics Group, Wageningen, $95 \mathrm{pp}$.

Ter BraAk, C. J. F. \& Šmilauer, P. (2002): CANOCO reference manual and CanoDraw for Windows User's guide: Software for Canonical Community Ordination (version 4.5). - Microcomputer Power, Ithaca, $499 \mathrm{pp}$.

Tropek, R., Hejda, M., Kadlec, T. \& Spitzer, L. (2013): Local and landscape factors affecting communities of plants and diurnal Lepidoptera in black coal spoil heaps: Implications for restoration management. - Ecological Engineering 57: 252-260. https://doi. org/10.1016/j.ecoleng.2013.04.024

Tsafack, N., Rebaudo, F., Wang, H., Nagy, D. D., Xie, Y., Wang, X. \& Fattorini, S. (2019): Carabid community structure in northern China grassland ecosystems: Effects of local habitat on species richness, species composition and functional diversity. - PeerJ 6: e6197. https://doi.org/10.7717/peerj.6197

Tuf, I. H., DedeK, P. \& Veselý, M. (2012): Does the diurnal activity pattern of carabid beetles depend on season, ground temperature and habitat? - Archives of Biological Sciences 64: 721-732. https://doi.org/10.2298/ABS1202721T

Van Heerdt, P. F., Blokhuis, B. \& Van HaAften, C. (1976): The reproductive cycle and age composition of a population of Pterostichus oblongopunctatus (Fabricius) in The Netherlands (Coleoptera: Carabidae). - Tijdschrift voor Entomologie 119: 1-15.

Weibull, A.-C., Östman, Ö. \& Granqvist, Å. (2003): Species richness in agroecosystems: the effect of landscape, habitat and farm management. - Biodiversity and Conservation 12: 1335-1355. https://doi.org/10.1023/A:1023617117780

WhitTAKer, R. H. (1972). Evolution and measurement of species diversity. - Taxon 21: 213251. https://doi.org/10.2307/1218190

YANG, Z., Cohen, W. B. \& HARmon, M. E. (2005): Modeling early forest succession following clear-cutting in western Oregon. - Canadian Journal of Forest Research 35: 1889-1900. https://doi.org/10.1139/x05-132

Received March 26, 2020, accepted November 18, 2020, published December 28, 2020 


\section{APPENDICES}

Appendix 1. Total number of carabid beetle species and individuals collected at the individual study sites in the years of the study (2009-2018).

\begin{tabular}{llrrrrrrrrrr}
\hline \multirow{2}{*}{ Plot } & Species/ & 2009 & 2010 & 2011 & 2012 & 2013 & 2014 & 2015 & 2016 & 2017 & 2018 \\
& individuals & & & & & & & & & & \\
\hline 14 & Species & 14 & 13 & 12 & 14 & 11 & 15 & 17 & 17 & 16 & 12 \\
& Individuals & 108 & 77 & 112 & 204 & 179 & 80 & 171 & 119 & 104 & 161 \\
16 & Species & 8 & 10 & 11 & 14 & 14 & 17 & 11 & 14 & 18 & 14 \\
& Individuals & 26 & 39 & 21 & 94 & 133 & 83 & 106 & 33 & 70 & 163 \\
17 & Species & 14 & 17 & 18 & 22 & 17 & 14 & 20 & 10 & 12 & 11 \\
& Individuals & 63 & 94 & 147 & 91 & 122 & 127 & 116 & 29 & 63 & 236 \\
18 & Species & 17 & 22 & 18 & 20 & 16 & 16 & 16 & 10 & 16 & 16 \\
& Individuals & 132 & 263 & 192 & 119 & 272 & 158 & 179 & 95 & 156 & 417 \\
19 & Species & 17 & 17 & 16 & 16 & 12 & 15 & 14 & 11 & 20 & 14 \\
& Individuals & 65 & 86 & 96 & 74 & 77 & 166 & 98 & 32 & 264 & 217 \\
20 & Species & 8 & 3 & 5 & 4 & 5 & 6 & 7 & 8 & 4 & 9 \\
& Individuals & 26 & 18 & 17 & 57 & 224 & 14 & 37 & 12 & 18 & 62 \\
21 & Species & 14 & 14 & 11 & 16 & 11 & 8 & 11 & 15 & 11 & 15 \\
& Individuals & 146 & 83 & 158 & 208 & 247 & 86 & 35 & 86 & 316 & 138 \\
35 & Species & 15 & 13 & 11 & 13 & 11 & 10 & 8 & 9 & 15 & 14 \\
& Individuals & 110 & 108 & 88 & 102 & 182 & 30 & 31 & 33 & 89 & 118 \\
\hline \multirow{2}{*}{ Sum } & Species & 44 & 46 & 44 & 49 & 33 & 36 & 44 & 40 & 49 & 40 \\
& Individuals & 676 & 768 & 831 & 949 & 1436 & 744 & 773 & 439 & 1080 & 1512 \\
\hline \multirow{3}{*}{16} & & & & & & & & & &
\end{tabular}

Appendix 2. Yearly mean temperature $\left({ }^{\circ} \mathrm{C}\right)$ and total precipitation $(\mathrm{mm} /$ year $)$ in the years of study (Temp, Prec) and in the year before the respective year (Temp before (Prec before $_{\text {be }}$ ).

\begin{tabular}{lrccc}
\hline Year & Temp & Prec & Temp $_{\text {before }}$ & Prec $_{\text {before }}$ \\
\hline 2009 & 8.09 & 527.1 & 9.37 & 589.8 \\
2010 & 7.28 & 767.0 & 8.09 & 527.1 \\
2011 & 8.86 & 571.6 & 7.28 & 767.0 \\
2012 & 8.54 & 778.1 & 8.86 & 571.6 \\
2013 & 8.48 & 662.4 & 8.54 & 778.1 \\
2014 & 9.71 & 484.5 & 8.48 & 662.4 \\
2015 & 9.68 & 302.4 & 9.71 & 484.5 \\
2016 & 9.23 & 425.4 & 9.68 & 302.4 \\
2017 & 8.97 & 687.8 & 9.23 & 425.4 \\
2018 & 10.00 & 377.4 & 8.97 & 687.8 \\
\hline
\end{tabular}


Appendix 3. Distance from the nearest forest (m) (Distance), age in 2011 and 2015 (Age), carbon content (C\%) in the organic layer in 2011 and $2015\left(\mathrm{C}_{\mathrm{org}}\right)$, and carbon content $(\mathrm{C} \%)$ in the mineral soil in 2011 and $2015\left(\mathrm{C}_{\min }\right)$ for the study sites.

\begin{tabular}{crrrrrrr}
\hline \multirow{2}{*}{ Study site } & \multirow{2}{*}{ Distance } & \multicolumn{3}{c}{ Age } & \multicolumn{2}{c}{$\mathrm{C}_{\text {org }}$} & \multicolumn{2}{c}{$\mathrm{C}_{\text {min }}$} \\
\cline { 2 - 8 } & & 2011 & 2015 & 2011 & 2015 & 2011 & 2015 \\
\hline 14 & 0 & 14 & 18 & 29.233 & 31.117 & 1.307 & 1.463 \\
16 & 0 & 33 & 37 & 31.523 & 35.400 & 0.846 & 2.600 \\
17 & 50 & 1 & 1 & 0.000 & 0.000 & 2.088 & 2.145 \\
18 & 100 & 0 & 0 & 0.000 & 0.000 & 2.037 & 1.917 \\
19 & 150 & 1 & 1 & 0.000 & 0.000 & 1.983 & 2.220 \\
20 & 0 & 69 & 73 & 33.960 & 29.347 & 1.543 & 1.547 \\
21 & 0 & 84 & 88 & 32.630 & 30.730 & 3.511 & 2.920 \\
35 & 0 & 12 & 16 & 30.557 & 25.120 & 1.201 & 1.240 \\
\hline
\end{tabular}

